\title{
The Organizational Support of Oversea Expatriates in Global Manufacturing Environment: the Case of Taiwanese Companies in Vietnam
}

\author{
Yi-Tzu Chung and Chenter Ho
}

\begin{abstract}
Due to the fierce competition globally, most of the manufacturing companies seek for low cost manufacturing resources globally to keep their competitiveness. In most of the cases, the core management team of these manufacturing factories is consisted of expatriates from other countries. The retention of these expatriate is one of the most troublesome issues in human resource management in these companies. In this paper, the effects of organizational supports on the retention of expatriates were studied. We collected information through survey of more than 50 Taiwanese companies in Vietnam and interviewed 10 executive managers who are working at Taiwanese companies in Vietnam. After analyzing the results of survey and interviews, the finding of this research are:
\end{abstract}

1. The perceived organizational supporting: expatriate trainings mostly focus on technical skills but not skills on crossing cultural barriers and other living information.

2. The perceived organizational supporting has positive effect on the oversea adjustment.

3. The oversea adjustment has positive effect to their intention to stay in Vietnam.

4. The perceived organizational supporting is showing positively influencing to their intention to stay in Vietnam. The oversea adjustment is a mediating factor between the perceived organizational supporting and their intention to stay in Vietnam.

The results of this research suggest that holistic support from the company is a key factor for expatriate to stay comfortable in Vietnam. That would also be the key to the successful business of the company in Vietnam.

Index Terms-Global manufacturing, organizational support, oversea adjustment, oversea expatriate.

\section{INTRODUCTION}

\section{A. Study the Motive}

Too domestic to still accredit a Vietnamese cadre after sending to some other department to the Taiwan trader at present, overseas to meet and keep wanton to wish research of depth appear relatively, in view of the above, research this to accredit a Vietnam cadre so as to the Taiwan trader for the sample, beyond send by angle of factor cadre to meeting and not it is be wanton to keep relation lasted discussed between not wishing abroad; So research this except explore existing to study China and foreign countries

Manuscript received February 15, 2012; revised March 20, 2012

Y.-T. Chung is PhD student of National Kaohsiung of Applied Sciences,Taiwan(e mail:geasy77@yahoo.com.tw).

C. Ho is with National Kaohsiung of Applied Sciences, Taiwan(e mail:hoc@cc.kuas.tw). send cadre to study in China and foreign countries send cadre to meet and leave wanton relation between wishing abroad, let the organization find the feasible impetus during the process of making great efforts to improve.

\section{B. Study the Purpose}

Research this probe into these choose the south enter Taiwan trader enterprise of Vietnam is it enter this piece full of chances but at the area not developed yet to fall over each other, it is because of the environment of the political economy early, enterprises have faced various kinds of problems of sending the selection, training of the Vietnamese cadre to some other department, letting etc., but open time is the longer with Vietnam, in addition, have six major competitions advantages, enterprises which enter Vietnam are the more in figure, already some people at present (or take the family dependent). Vietnam of cadre to some other department with leave wanton to wish to increase, reach the goal with win-win labor and capital finally, in addition, the relation of one that this research will probe into staff's personal attribute and each become.

\section{DOCUMENT DISCUSSION}

\section{A. Meet and Keep the Wanton Relevant Research that Wish Overseasly}

Castles[1] propose it is a kind of world tide that the labourer moves, because the capital and production concentrate on needing laborers to move, combine with information and revolutionary innovation of control technology, change the global laborer and is distributed, cause the new international migration (Cai Ming field,etc., [2]). No matter send it to the overseas foreign labourer of international cadre or international migration, form ' the sojourner 's promptly as to enterprise (sojourner). What is called ' the sojourner ' reside other different cultural area persons abroad in a short time, do not point and reside the foreign immigrant for a long time. Because being different from social background, cultural race does not originally know how about to meet in the locality and the behavior suit under the culture that the locality has had effectively (Mendenhall, 1988, Mendenhall \& Oddou, [3]). At this moment, while sending a cadre to some other department and placing oneself in the midst of differently to the strange environments familiar with, used toinged of usual, is it offend against taboo or improper to produce anxious, sensitive or psychology uncomfortable feeling behavior to fear to know, Oberg [4] calls this kind of phenomenon "cultural shock (Cultural shock)". 


\section{STUDY}

\section{A. Study the Structure}

It is influencing accrediting Vietnamese personnel's overseas adaptation in Vietnam's long-term development and keep wanton and willing that this research is being probed into mainly, among them regard organization's supporting consciousness as and change one by oneself, meet and change one for the intermediary overseasly, keep wanton to wish for in accordance with become item, is it organize consciousness of supporting etc. to meet, leave wanton influence and each other's interaction.

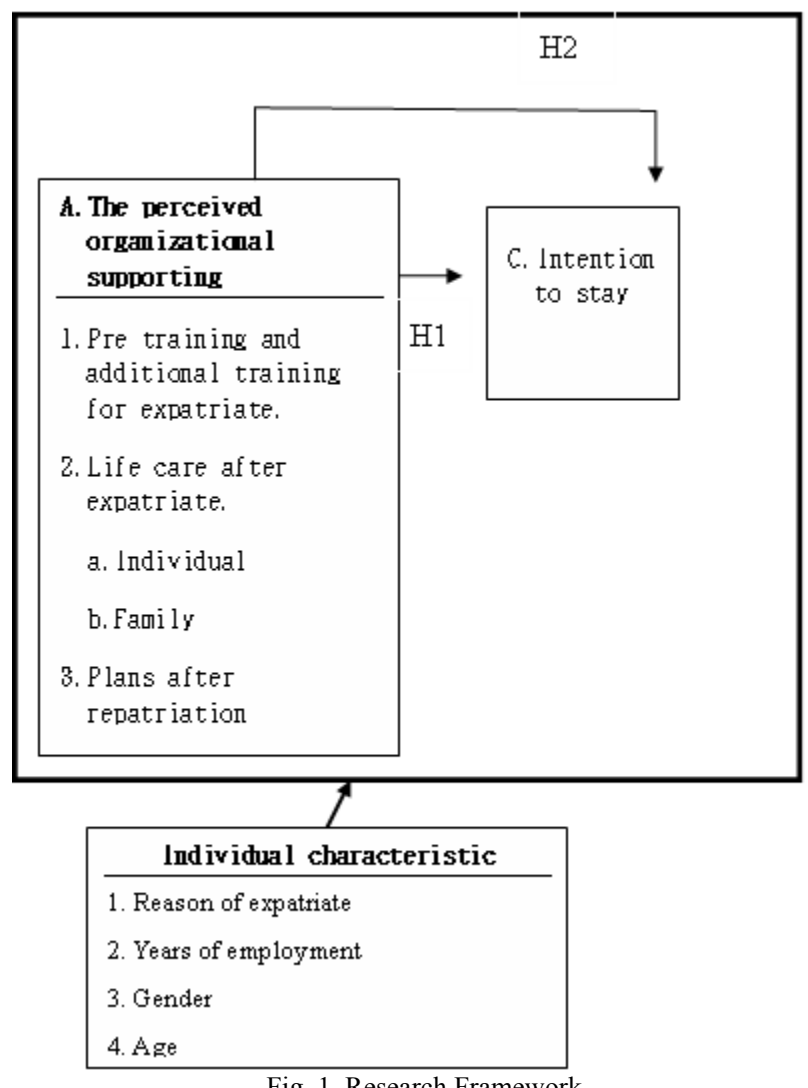

Fig. 1. Research Framework.

\section{B. Research Supposing}

Inference probed into according to idea research structure and document of Fig. 1 in this research, depend on the relation of every parameter, develop out research under this research to suppose:

TABLE I: THE RESEARCH HYPOTHESES

[Research suppose H 1], different personal characteristic meet, have apparent to the difference on keeping wanton to wish abroad.

H 1-1: A different one sends to some other department reason meet, have apparent to influence on keeping wanton to wish abroad.

$\mathrm{H}$ 1-2: Different service age and service seniority meet, have apparent to influence on keeping wanton to wish abroad.

H 1-3: Different sex meet, have apparent to influence on keeping wanton to wish abroad.

H 1-4: Different age meet, have apparent to influence on keeping wanton to wish abroad.

[Research supposes $H$ 2] suit overseasly and wish to have to leaving wantonly apparently to influence.

$\mathrm{H}$ 2-1: Life meets and wishes to have to keeping want only apparently to influence.

H 2-2: Work and acculturation wish to have to keeping wantonly apparently to influence.

\section{Study the Operation Which Changes One to Define and Weigh}

This research regards questionnaire as and studies tools, relevant documents are defined and designed according to the research structure and research parameter through consulting, will prove as follows now:

First, adapt to constructing the surface overseasly: It refers to the interdynamic relation among individual and environment to meet overseasly, can divide in order to suit and generally suit interdynamically, this research, according to Niehoff \& Moorman (1993) View,construct surface divide into, ' work with acculturation ' go on not weighing. ' the environment ' while originally grinding refers to various kinds of external things related to individual in general, person, thing, thing that for instance touch in the family, school, work, etc; It refers to its mutual relation and influence that interdynamic ( Wu WuDian, have justice bigly, 1987). (1964) Think that it is a kind of course to adapt to, through this course, individual forms a kind of ' harmonious ' and ' balanced relation ' instead of the environment of living in, and the condition that this kind of relation need. Second, keep wanton and wish to construct the surface: Fan JingLi (1978) Think and leave office the will means individual intents to leave the present work position, look for the intensity of inclination of other working opportunities in addition. (1979) Think that the will is to leave and look for the overall behavior or attitude that other working opportunities are inclined to to leave office. Liu JunChang (2000) have described, one that is with positive one ' retain the office ' is defined backward ' leave office ', namely like to stay and continue rendering a service in order to organize inside the organization.

\section{Analytical Method of the Materials}

This research, according to studying the purpose and assaying the need that is supposed, use person who describe statistical analysis, exploratory factor divide into, letter degree analyse, and is it analyse to reply to count to make a variation, count the software and carry on the data analysis with SPSS 12.0 for windows.

\section{RESEARCH AND ANALYSE AND DISCUSS}

\section{A. Narrating Statistical Analysis}

Learnt by the narration statistical distribution result that this research retrieves 150 effective samples:

First, send the Vietnamese main reason to some other department and is distributed: Among the sample of one that is in 150 valid questionnaire, with ' strive for freely, is it let Vietnam to send voluntarily ' have 49 people, account for $32.5 \%$, ' appoint by company, is it is it is it get Vietnam to let to send to repel ' have 79 people, accounting for $52.3 \%$, it has 10 people ' if not the company appoints, otherwise there is no will to work for Vietnam ', accounting for $6.6 \%$, ' other ' have 13 people, take $8.6 \%$, show if the company appoints domestic staff, most staff (up to $91.4 \%$ ) Will not repel and work for Vietnam.

Second, the parent company serves the age and service seniority: With one year (include) There are 23 people as follows, accounting for $15.2 \%$, there are 53 people in 2 , 
accounted for $35.1 \%$, there are 33 people in 60 , accounts for $21.9 \%$, there are 15 people in 115 , accounting for $9.93 \%$, there are 27 people in 160 , accounted for $17.9 \%$, this show average age and service seniority between the 2 years in staff that parent company serve also ( Accounts for 35.1\%) .

Third, age and service seniority that work overseasly: One year (include) There are 43 people as follows, accounting for $28.5 \%$, there are 83 people in 2 , accounted for $54.9 \%$, there are 14 people in 60 , accounts for $9.3 \%$, there are 11 people in 115, accounts for $7.3 \%$, can understand from analysis, the age and service seniority, for 2 years on average of worker abroad (account for $54.9 \%$ ) .

Fourth, the sex is distributed: There are 138 men, accounts for $91.4 \%$, there are 13 women, accounts for $8.6 \%$, third, age and service seniority of service of the parent company is analysed.

TABLE II: THE NARRATING STATISTICAL ANALYSIS

\begin{tabular}{|c|c|c|c|}
\hline $\begin{array}{c}\text { The sample of watch } 1 \text { counts the statistical form } n=150 \\
\text { Attribute of the parameter }\end{array}$ & Select & $\begin{array}{l}\text { Number of } \\
\text { people }\end{array}$ & $\begin{array}{l}\text { Percentag } \\
\quad \text { e } \%\end{array}$ \\
\hline \multirow[t]{4}{*}{ 1. Send the Vietnamese main reason to some other department } & $\begin{array}{l}\text { Freedom striving for, send and take the post as } \\
\text { Vietnam voluntarily }\end{array}$ & 53 & $35.3 \%$ \\
\hline & $\begin{array}{l}\text { Appointed by the company, but not repel } \\
\text { sending to let to Vietnam }\end{array}$ & 71 & $47.3 \%$ \\
\hline & $\begin{array}{l}\text { If not the company appoints, otherwise there is } \\
\text { no will to work for Vietnam }\end{array}$ & 9 & $6.0 \%$ \\
\hline & Other & 17 & $11.3 \%$ \\
\hline \multirow{4}{*}{ 2. Age and service seniority of mother's company service } & 25 years of 2 & 44 & $29.3 \%$ \\
\hline & 610 years of 6 & 37 & $24.7 \%$ \\
\hline & 1115 years of 11 & 23 & $15.3 \%$ \\
\hline & 1620 years of 16 & 25 & $16.7 \%$ \\
\hline \multirow[t]{2}{*}{ 3. Sex } & Man & 136 & $90.7 \%$ \\
\hline & Women & 14 & $9.3 \%$ \\
\hline \multirow[t]{2}{*}{ 4. Age } & 25 years old (include) Following & 12 & $8.0 \%$ \\
\hline & 410 years old & 60 & $40.0 \%$ \\
\hline
\end{tabular}

\begin{tabular}{|c|c|c|c|}
\hline $\begin{array}{l}\text { The sample of } \\
\text { watch } 1 \text { counts } \\
\text { the statistical } \\
\text { form } n=150 \\
\text { Attribute of the } \\
\text { parameter }\end{array}$ & Select & $\begin{array}{l}\text { Number } \\
\text { of } \\
\text { people }\end{array}$ & $\begin{array}{c}\text { Percentage } \\
\%\end{array}$ \\
\hline \multirow{4}{*}{$\begin{array}{l}\text { 5. Send the } \\
\text { Vietnamese } \\
\text { main reason } \\
\text { to some } \\
\text { other } \\
\text { department }\end{array}$} & $\begin{array}{l}\text { Freedom striving for, } \\
\text { send and take the post } \\
\text { as Vietnam voluntarily }\end{array}$ & 53 & $35.3 \%$ \\
\hline & $\begin{array}{l}\text { Appointed by the } \\
\text { company, but not repel } \\
\text { sending to let to } \\
\text { Vietnam }\end{array}$ & 71 & $47.3 \%$ \\
\hline & $\begin{array}{l}\text { If not the company } \\
\text { appoints, otherwise } \\
\text { there is no will to } \\
\text { work for Vietnam }\end{array}$ & 9 & $6.0 \%$ \\
\hline & Other & 17 & $11.3 \%$ \\
\hline \multirow{5}{*}{$\begin{array}{l}\text { 6. Age and } \\
\text { service } \\
\text { seniority of } \\
\text { mother's } \\
\text { company } \\
\text { service }\end{array}$} & $\begin{array}{c}\text { One year (include) } \\
\text { Following }\end{array}$ & 21 & $14.0 \%$ \\
\hline & 25 years of 2 & 44 & $29.3 \%$ \\
\hline & 610 years of 6 & 37 & $24.7 \%$ \\
\hline & 1115 years of 11 & 23 & $15.3 \%$ \\
\hline & 1620 years of 16 & 25 & $16.7 \%$ \\
\hline \multirow{2}{*}{ 7. Sex } & Man & 136 & $90.7 \%$ \\
\hline & Women & 14 & $9.3 \%$ \\
\hline \multirow{4}{*}{ 8. Age } & $\begin{array}{c}25 \text { years old (include) } \\
\text { Following } \\
\end{array}$ & 12 & $8.0 \%$ \\
\hline & 260 years old & 26 & $17.3 \%$ \\
\hline & 310 years old & 52 & $34.7 \%$ \\
\hline & 410 years old & 60 & $40.0 \%$ \\
\hline
\end{tabular}

The difference that is each constructing the surface in research this assumption $\mathrm{H} \mathrm{1-3}$ different age and service show too the company sends personnel to some other department, man are $80 \%$ more than women (man: Women =9: 1).

Is it show Taiwan trader result, enterprise of internationalization to analyse while being above-mentioned to synthesize, this also shows and sends a cadre to some other department that would like to accept the task of sending to some other department on the basis of economic factor, family counterpart is it accredit ground Vietnam person still been great majority to live in (Accounts for $88.1 \%$ ), seniority meet abroad with with leave wanton to wish that there is difference of showing for person who prove, found finally: Different age and service seniority meets difference of showing abroad, relatively found by Scheffe, the overseas adaptation which serves the the higher one of age and service seniority is generally greater than the lower one of age and service seniority. Only keep wanton and wish that has not shown the difference in serving the age and service seniority, analyse unanimity in difference between this result and different overseas age and service seniority, different education degree and different ages.

TABLE III: THE NARRATING STATISTICAL ANALYSIS

\begin{tabular}{|c|c|c|}
\hline $\begin{array}{c}\text { 3 form keep wanton person who wish } \\
\text { form construct surface suggestion } \\
\text { mean value of one } \\
\text { Weigh the question one }\end{array}$ & Average & $\begin{array}{c}\text { Standard } \\
\text { deviation }\end{array}$ \\
\hline Keep wanton to wish & $\mathbf{3 . 2 6}$ & $\mathbf{1 . 1 4 9}$ \\
\hline $\begin{array}{c}\text { 1.If because the company needs me to } \\
\text { work in Vietnam for a long time, } \mathbf{I} \\
\text { would like to continue staying in } \\
\text { Vietnam and developing }\end{array}$ & 3.49 & 0.817 \\
\hline $\begin{array}{c}\text { 2.If the need of family's economic factor, } \\
\text { I would like to continue staying in } \\
\text { Vietnam and serving }\end{array}$ & 2.73 & 1.028 \\
\hline $\begin{array}{c}\text { 3.When the company has had no necessity } \\
\text { stationed abroad to me yet, I would still } \\
\text { like to stay in Vietnam and serve }\end{array}$ & & \\
\hline
\end{tabular}

Note: $* \mathrm{p}<.05 * * \mathrm{p}<. \quad 01 * * * \mathrm{p}<.001$

Research this it shows to be may because heavy to serve long and different education degree in not organizing age, not familiar with the working content of the position from the beginning, pass the accumulation of constant experience, 
have driven a light carriage on a familiar road to the work gradually, and with the promotion of the position, make staff's social status in organizing promote gradually, then can be to meeting the influence power of producing a kind of front abroad gradually. So this research supposes that obtains the part to support by 1-3.

Fifth, sex construct variation of surface count and analyse each.

TABLE IV: THE F VALUE ANALYSIS

\begin{tabular}{|c|c|c|c|c|}
\hline $\begin{array}{c}\text { Each constructing the } \\
\text { surface and making a } \\
\text { variation and counting } \\
\text { analysing in sex of } \\
\text { watch 8 } \\
\begin{array}{c}\text { Construct the } \\
\text { surface }\end{array}\end{array}$ & Factor & $\begin{array}{c}\text { S)Man } \\
\mathbf{( n = 1 3 8 )}\end{array}$ & $\begin{array}{c}\text { B)Women } \\
(\mathbf{n}=\mathbf{1 3})\end{array}$ & $\begin{array}{c}\text { F } \\
\text { value }\end{array}$ \\
\cline { 3 - 4 } Keep wanton to wish & $\begin{array}{c}\text { Keep } \\
\text { wanton } \\
\text { to wish }\end{array}$ & 3.1825 & 2.9524 & $0.005^{*}$ \\
\hline
\end{tabular}

Note: $* \mathrm{p}<.05 * * \mathrm{p}<. \quad 01 * * * \mathrm{p}<. \quad 001$

\section{B. Analyse}

It is from form for 14 can know, it suit abroad (for example: Food-There are one's own cadre's exclusive restaurants, offer the self-service breakfast, lunch and dinner free; Clothing - Offer the abundant work clothes, the professional nurse likes to iron the clothes; Live - The professional nurse sweeps the room with changing and liking the bedding every day; Yes - There are officer's cars and full-time drivers; Breed-Gymnasium; Happy-Karaoka disc and most fashionable Wii game machine wait) Part, in order to construct surface is it is it to leave wanton to wish relation between, may understand from ${ }_{\mid} \hat{\mathrm{A}}$ value to probe into to go separately each, between work.

\begin{tabular}{|c|c|c|c|c|}
\hline $\begin{array}{l}\text { Form } 14 \text { adapts } \\
\text { to wishing to } \\
\text { analyse in } \\
\text { keeping wanton } \\
\text { overseasly } \\
\text { Put a order into } \\
\text { the parameter }\end{array}$ & $\begin{array}{l}\text { Standardization } \\
\text { Return to } \\
\text { coefficient Beta }\end{array}$ & $\begin{array}{c}\text { Determine } \\
\text { Coefficient } \\
\text { R2 }\end{array}$ & $\begin{array}{c}\text { R2 } \\
\text { Changing } \\
\text { amount }\end{array}$ & $\mathrm{F}$ value \\
\hline
\end{tabular}

\section{Research is Supposed with the Real Example Result}

According to the real example result of chapter four, and state while being above-mentioned, research suppose remit as form 16 shows whole with real example result of study research this now.

TABLE V: THE RESUlt ANALYSIS

\begin{tabular}{|c|c|}
\hline $\begin{array}{c}\text { The research of watch } 15 \text { supposes that gather } \\
\text { together and exactly express with the real example } \\
\text { result } \\
\text { Research supposing }\end{array}$ & Result of study \\
\hline \multicolumn{2}{|c|}{$\begin{array}{l}\text { [Research suppose } 1 \mathrm{H} \text { ], different personal characteristic meet, have } \\
\text { apparent to the difference on keeping wanton to wish abroad. }\end{array}$} \\
\hline $\begin{array}{l}\text { H 1-1: A different one send to some other } \\
\text { department reason meet, have apparent to influence } \\
\text { on keeping wanton to wish abroad. }\end{array}$ & Untenable \\
\hline $\begin{array}{l}\text { H 1-2: Different service age and service seniority } \\
\text { meet, have apparent to influence on keeping wanton } \\
\text { to wish abroad. }\end{array}$ & Establish partly \\
\hline $\begin{array}{l}\text { H 1-3: Different sex meet, have a } \\
\text { influence on keeping wanton to wish abro }\end{array}$ & Establish \\
\hline $\begin{array}{l}\text { H 1-4: Different age meet, have apparent to } \\
\text { influence on keeping wanton to wish abroad. }\end{array}$ & Establish partly \\
\hline \multicolumn{2}{|c|}{$\begin{array}{l}\text { [Research suppose } 2 \mathrm{H} \text { ], overseas to meet to leave wanton to is it } \\
\text { have apparent to influence to wish. }\end{array}$} \\
\hline $\begin{array}{l}\text { H 2-1: Work and acculturation wish to have to } \\
\text { keeping wantonly apparently to influence. }\end{array}$ & Establish \\
\hline
\end{tabular}

TABLE VI: THE SCHEFFE ANALYSIS

\begin{tabular}{|c|c|c|c|c|c|c|c|}
\hline \multirow{2}{*}{$\begin{array}{c}\text { The difference that is each } \\
\text { constructing the surface in } \\
4 \text { different other reason of } \\
\text { group of forms is analysed } \\
\text { Construct the surface }\end{array}$} & Factor & $\begin{array}{c}\text { A)Initiatively } \\
\text { strive for } \\
(\mathbf{n = 4 9 )}\end{array}$ & $\begin{array}{c}\text { B)The company } \\
\text { appointing } \\
\text { ( n=79) }\end{array}$ & $\begin{array}{c}\text { C)There is } \\
\text { no will } \\
(\mathbf{n}=\mathbf{1 0})\end{array}$ & $\begin{array}{c}\text { D)Other } \\
\mathbf{( n = 1 3 )}\end{array}$ & F value & $\begin{array}{c}\text { Scheffe } \\
\text { comparing }\end{array}$ \\
\hline Keep wanton to wish & $\begin{array}{c}\text { Keep wanton } \\
\text { to wish }\end{array}$ & 3.2721 & 3.1097 & 3.0333 & 3.1538 & 0.616 & -- \\
\hline
\end{tabular}

Note: ${ }^{*} \mathrm{p}<.05 * * \mathrm{p}<. \quad 01 * * * \mathrm{p}<. \quad 001$

TABLE VII: THE SCHEFFE ANALYSIS

\begin{tabular}{|c|c|c|c|c|c|c|c|c|c|}
\hline \multirow{2}{*}{$\begin{array}{l}\text { Each constructing the } \\
\text { surface difference to } \\
\text { analyse in age and service } \\
\text { seniority of } 6 \text { parent } \\
\text { companies of the form } \\
\text { Construct the surface }\end{array}$} & \multirow[b]{2}{*}{ Factor } & \multicolumn{6}{|c|}{ Age and service seniority of mother's company service } & \multirow[b]{2}{*}{ F value } & \multirow[b]{2}{*}{$\begin{array}{l}\text { Scheffe } \\
\text { Compare }\end{array}$} \\
\hline & & $\begin{array}{c}(A) \\
\text { Under } \\
\text { one year } \\
(\mathbf{n = 2 3})\end{array}$ & $\begin{array}{c}(\text { B) } 2 \\
(n=53)\end{array}$ & $\begin{array}{c}(C) 60 \\
(n=33)\end{array}$ & $\begin{array}{l}\text { (D) } 115 \\
(n=15)\end{array}$ & $\begin{array}{l}(E) 160 \\
(n=14)\end{array}$ & $\begin{array}{c}\text { F)More than } 21 \\
\text { years } \\
(n=13)\end{array}$ & & \\
\hline Keep wanton to wish & $\begin{array}{c}\text { Keep } \\
\text { wanton to } \\
\text { wish } \\
\end{array}$ & 3.0870 & 3.0252 & 3.1919 & 3.2000 & 3.6190 & 3.2375 & 1.344 & -- \\
\hline
\end{tabular}

Fifth, sex construct variation of surface count and analyse each.

TABLE VIII: THE F VALUE ANALYSIS

\begin{tabular}{|c|c|c|c|c|}
\hline \multirow{2}{*}{$\begin{array}{l}\text { Each constructing the surface and making a variation and counting analysing in sex of watch } \\
8 \\
\text { Construct the surface }\end{array}$} & \multirow[b]{2}{*}{ Factor } & \multicolumn{2}{|c|}{ Sex state } & \multirow[b]{2}{*}{ F value } \\
\hline & & $\begin{array}{l}\text { A)Man } \\
(\mathrm{n}=\mathbf{1 3 8})\end{array}$ & $\begin{array}{c}\text { B)Women } \\
(n=13)\end{array}$ & \\
\hline
\end{tabular}




\section{CONCLUSION AND SUGGESTION}

\section{A. Study the Conclusion}

First, the personal characteristic, to the difference analysis that meet abroad.

Is it count with single factor between analysis and $t$ is it probe into personal personality special confrontation meet and have difference of showing to have abroad separately to assay to make a variation this festivals, these personal classifications change one including age, it is compared (Scheffe' s Multiple Comparison) again and many with Scheffe Compare the difference between two groups further. Become item because only 13 women send personnel to some other department among the sample several 151 people in sex, so not do difference analysis with the sex, explain the result of study as follows now:

\section{1) Send the other reason}

It understand at sample of one that is in questionnaire not valid staff not domestic send mainly to some other department into main fact to Vietnam by company.

2) The parent company serves the age and service seniority and is distributed

3) $\mathrm{Sex}$

Different sex has not shown the difference in life meet, in between work and acculturation, leave wanton to wish, it is man that greater than women all. Perhaps accredit the women cadre abroad and think that there is a ceiling effect of glass on the on-the-job field.

\section{4) Age}

Every group is keeping wanton and wishing to go to the group with supreme average for maybe 51-60 years old at age, is 3.37 , the standard deviation is 0.79 , the minimum group is maybe 26-30 years old, is 3.06, standard deviation 0.79 , every group keeping wanton to is it have difference slightly to wish, can is it keep wanton to wish that there will be a difference because of the change of age to know among the age, but research this age among 25-50 years old person, have obvious difference, can influence it leave wanton to wish either person who examine. See forms 4-5 in analysis result.

Secnd, comprehensive research supposes that can know with the real example result:

[Research suppose 1 H1], different personal characteristic meet, have apparent to the difference on keeping wanton to wish abroad. Verify the result: Establish partly.

[Research supposes H2] suit overseasly and wish to have to leaving wantonly apparently to influence. Verify the result: Establish partly

\section{B. Research Proposing}

First, suggestion on the business circles

1. Should pay attention to individual's initiative to the will stationed abroad while selecting to accredit other personnel, namely as personnel express the interest to the work stationed abroad, there is attitude of initiativelying strive for, he then reach Vietnam continue retain the office will right away high.

2. Company's policy should be offered on the chance that family live together of personnel stationed abroad, because for personnel stationed abroad, if family can live with it, can have heavy help very in life to spirit its then, though a lot of companies will offer family to the personnel stationed abroad to the chance that Vietnam visits at present, but it is still the minority that family live with sending other personnel together to stay on ground after all, certainly personnel's family are unwilling to go to Vietnam to live except that the company has not offered this chance, because send in addition, but if the assistance after can offer to its family of the company to the continent and relevant arrangements in life, or household may live in Vietnam such measures as half a year,etc. of the one year, will raise and send person household and will in Vietnam to some other department then, is it send someone personnel in to leave wanton to wish high Vietnam to make.

3. Some people want to develop oneself, pursue and grow up, can give play to the ability space, Vietnam is a very ideal place; Some people think that it can obtain faster chance of promotion or higher wages to get to Vietnam, so they would like to send lets to Vietnam, therefore can know the motive stationed abroad varies with each individual, enterprises can understand everybody's different demands while selecting the personnel stationed abroad, need to improve its motive stationed abroad to individual, the stronger the motive of acting as the personnel stationed abroad is, to to either heavy help have work performance, can increase it leave wanton to wish.

4. In stationed abroad to meet respect, work and in life adaptation can influence will that individual retain the post of directly all, so company should is it send other personnel find out about working content and characteristic their,etc. clearly to let, is it grasp working state to help, should offer in life assistance, make its ability good adaptation, and then increase it to keep wanton to wish.

5. In speciality of personality stationed abroad, in the task stationed abroad, when some specialities of personality stationed abroad are more conspicuous, can help to send personnel to some other department and have good adaptation, and then keep wanton to encourage it to wish, so enterprises should classify the personality factor as and select one of the conditions that accredits other personnel, or train its relevant ability.

6. Most enterprises, for sending the other cadre, the majority is to promote the chance by improving the wages and essence, go back home country receive a training of world manage essential skill and arrange proper to work and offer such 3 ways as working fulfillment,etc. sending to some other department and planning mainly, besides hoping to attract outstanding talents to go, and one, giving play to latent energy (one is acted as at least three people use) The simultaneous, like continuation retain the office serve this enterprise.

1. Second, suggestion on the government department:

2. Analysis result of this research, can fully offer a government to me when to that the Vietnamese Taiwan trader correlated with the policy of coaching to stipulates, important reference indicator.

3. Our government department can also gather via this research institute, understand voluntarily Taiwan trader's enterprises are when Vietnam expands the business, run into difficulty,such as Strike, declaring at the Customs, levying taxs with such assistance with legal advice as the uncertainty of the local government policy,etc.,etc., should 
offer concrete and essential assistance in good time as government's relevant departments.

Accept the person who sends task to some other department, its family forgives and common understanding, whether support it to continue retaining the office, become key point whether parties could continue retaining the office, the above needs to think twice.

Third, suggestion on follow-up study:

1. In a respect of studying the change: The choice of one that this research is being studied to become, is from the personal point of view, to the control organizing, or send other personnel to work without discussing with such factors as the conflict of the family,etc., so propose follow-up researcher can direct topic this against, is it join discuss item to increase, for example family's factor,etc., enable studying more intact.

In choice of the research object: This research, while choosing the research object, because is convenient to sample, the one that has not contained accreditting in all areas of Vietnam has sent a cadre to some other department, sending a cadre to some other department in order to accredit in the south of the majority, so propose the follow-up researcher, can be to sending all personnel to some other department of other areas ( Do not limit a cadre) Do further research.

\section{REFERENCES}

[1]. Castle, Clear under the wood, the human resources are transfered overseasly- send personnel to check and rate overseasly, Kyoto of Japan: Open the gentle society, 1983.

[2]. Cai Ming field, I will help tomorrow, "the foreign labourer in Taiwan will step acculturation case study", the relation between labour and capital talks about the clump, volume seven, pp. 185-193, 1998.

[3]. M. Mendenhall and G. Oddou, "The Dimensions of Expatriate Acculturation," Academy of Management Review, vol.10, no.1, pp. $39-47,1985$.

[4]. K. Oberg. 1960. Culture shock: adjustment to new culture environment.Practical Anthropologist, vol. 7, pp. 177-182.

[5]. R. L. Tung and E. L. Miller, " Managing in the Twenty-first Century: The Need-for Global Orientation," Management International Review, vol. 30, no.1, pp.5-18, 1990.

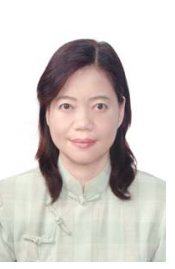

Yi-Tzu Chung was born in Pingtong, Tai Wan, R.O.C. I was graduated at from NCKU and majored in Business Administration many years ago, By the way, My majority is the Human Resource Development of EMBA degree at National Kaohsiung University of Applied Science. And just became a Member (M). I'm a helpful girl and I'm so glad to have the pleasure to enroll in my esteem 'phD program', even There's no humbles here, especially I am a consultant In Business Administration, production, marketing, HR, R\&D, Finnace and Information system and so on. I think I'm tough not only physically but mentally. I'm tender and friendly and helpful also "I'm easy to be approached, I'm interested in coping and communication and making an excellent deal and promoting the thought to the end user"also . 